\title{
Jewish Studies and Reading
}

\author{
Document Version \\ Proof
}

Link to publication record in Manchester Research Explorer

\section{Citation for published version (APA):}

Samely, A. (2016). Jewish Studies and Reading. In G. Langer, \& C. Cordoni (Eds.), 'Let the Wise Listen and Add to Their Learning': Festschrift for Günter Stemberger on the Occasion of his 75th Birthday (pp. 757-789). (Studia Judaica; Vol. 90). de Gruyter, Walter GmbH \& Co. https://www.degruyter.com/viewbooktoc/product/460732

\section{Published in:}

'Let the Wise Listen and Add to Their Learning'

\section{Citing this paper}

Please note that where the full-text provided on Manchester Research Explorer is the Author Accepted Manuscript or Proof version this may differ from the final Published version. If citing, it is advised that you check and use the publisher's definitive version.

\section{General rights}

Copyright and moral rights for the publications made accessible in the Research Explorer are retained by the authors and/or other copyright owners and it is a condition of accessing publications that users recognise and abide by the legal requirements associated with these rights.

\section{Takedown policy}

If you believe that this document breaches copyright please refer to the University of Manchester's Takedown Procedures [http://man.ac.uk/04Y6Bo] or contact uml.scholarlycommunications@manchester.ac.uk providing relevant details, so we can investigate your claim.

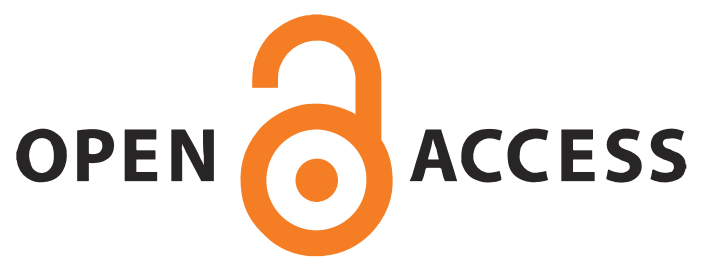




\section{Alexander Samely Jewish Studies and Reading}

Jewish Studies today is not restricted to the methodological and evidential paradigms of nineteenth-century Wissenschaft des Judentums. This is not to deny that those parts of the discipline which belong to the historical humanities still nourish themselves from the historical and philological achievements of that Wissenschaft. But other dimensions have changed considerably. Not only have Jewish Studies expanded into many non-philological areas, including historical, social, anthropological and cultural research into non-elite expressions of Jewishness very different in nature from the religious-textual traditions of Judaism. The scholarly practice of studying the religious-textual evidence itself has seen important additions and changes to the procedures used by Zunz, Geiger and Steinschneider. Perhaps the most profound change affects the very notion of what it means to read a text for academic purposes. Assumptions that used to underpin how practically all scholars read their sources, Jewish or otherwise, have become challenged and, in the case of some contemporary approaches in Jewish Studies, abandoned. Conceptual issues surrounding reading strongly affect the academic methodology of studying the textual heritage of Judaism. The reason for this is that many primary texts are readings of earlier primary texts, with both the earlier and the later text preserved for academic inspection. So text-oriented Jewish Studies find themselves at the very centre of a storm blowing through the humanities, the crisis of reading, because of the centrality of reading as a cultural practice in certain strands of Jewish culture. In this paper I explore how the study of Jewish sources is affected by a number of trends in the conceptualization and practice of reading. I touch upon psychological and phenomenological approaches to reading, the post-modern challenge to the ideas of stable text meaning and text coherence, the role of Jewish identity among Jewish Studies academics as readers, and one important illustration of the scholarly reading of Jewish reading, the study of rabbinic Midrash.

\section{Jewish Studies as a Discipline Concerned with Cultures of Reading}

The Jewish cultural practice of reading texts closely goes back to the time when the Hebrew Bible was still being formed. At first, earlier "biblical" texts were 
adapted, added to, and continued. ${ }^{1}$ Later, when biblical documents became increasingly accepted as closed, they were frequently imitated, translated, paraphrased and explained. Reading biblical documents thus produced new texts, now marked as standing alongside the biblical ones. Engaging with existing texts through close readings became a central method for Jews to generate or display new ideas and to communicate meanings. The genres of literature which engaged with Scripture in the Second Temple and rabbinic periods include: rewritten Scripture; Aramaic and Greek versions of the biblical writings; detailed sequential commentaries, as found among Philo's works, in Qumran Pesher, and the so-called "exegetical" Midrashim of the rabbinic centuries; and thematic-Scriptural expositions, nowadays called "homiletic” Midrash. ${ }^{2}$ Qumran manifests an intensely biblical milieu expressed in a variety of literary genres, while most texts of the New Testament reflect some level of engagement with the then biblical texts. One finds many individual biblical quotations scattered in texts devoted to normative, spiritual and mystical exposition, and to narrative and prayer. The earliest thematic text of the rabbinic period, the Mishnah of the third century C.E., contains only a few hundred explicit biblical quotations dispersed among its various topics; ${ }^{3}$ the somewhat later Tosefta contains proportionally many more; and in post-Talmudic thematic texts, from Maimonides' Mishneh Torah to Shneur Zalman of Liady's Tanya, they constitute a routine presence in varying degree. Jewish literary production since antiquity has continued to take place against the background of a dialogue with the Bible. ${ }^{4}$ But new,

1 For the analysis of inner-canonical Fortschreibungen see recently for instance, Michael Lyons, From Law to Prophecy: Ezekiel's Use of the Holiness Code (New York, London: Clark, 2009); Jacob Stromberg, Isaiah After Exile: The Author of Third Isaiah as Reader and Redactor of the Book (Oxford: Oxford University Press, 2011); William A. Tooman, God of Magog: Reuse of Scripture and Compositional Technique in Ezekiel 38-39 (Tübingen: Mohr Siebeck, 2011); D. Andrew Teeter, Scribal Laws: Exegetical Variation in the Textual Transmission of Biblical Law in the Late Second Temple Period (Tübingen: Mohr Siebeck, 2014); for an overview, see Reinhard G. Kratz, "Redaktionsgeschichte/Redaktionskritik I," in Theologische Realenzyklopädie, ed. G. Müller etal., vol. 28 (Berlin, New York: de Gruyter, 1997), 367-378.

2 See in particular the relevant chapters in Günter Stemberger, Einleitung in Talmud und Midrasch, $9^{\text {th }}$ ed. (Munich: Beck, 2011); English: Introduction to the Study of Talmud and Midrash, trans. M. Bockmuehl, $2^{\text {nd }}$ ed. (Edinburgh: Clark, 1996), 233-325; Alex Samely, Forms of Rabbinic Literature and Thought: An Introduction (Oxford: Oxford University Press, 2007), 64-96; 178-99.

3 Alex Samely, Rabbinic Interpretation of Scripture in the Mishnah (Oxford: Oxford University Press, 2002); Alex Samely, Database of Midrashic Units in the Mishnah (2003, http://mishnah. llc.manchester.ac.uk/about.aspx, accessed 18/05/2015).

4 Cp. Günter Stemberger, Geschichte der jüdischen Literatur: Eine Einführung (Munich: Beck, 1977), 9, who speaks of the Hebrew Bible as "Grundstein fast allen literarischen Schaffens des Judentums." 
additional objects of hermeneutic desire entered the picture, starting with the Mishnah. The Gemaras constitute themselves primarily as readings of the Mishnah, but that did not prevent the Babylonian Gemara from becoming an object of cultural projects of reading in its own right, joining Scripture and Mishnah in attracting commentaries and super-commentaries, summaries and rearrangements. The process continued thereafter, and there has been an ever-growing body of works such as Zohar, Shulchan Arukh and many less influential ones, that have become the target of readings embodied in new texts. Furthermore, in antiquity the allegiance to certain canons and certain hermeneutic practices regarding those canons appears to have demarcated religious and other differences within Judaism. That practice too, has proved long-lived; in the modern period Jewish groups continue to differentiate along the lines of reading and valuing certain texts, and not others, recalling the Aqivan injunction in the Mishnah (mSan 10.1) against those who "read outside books." Jewish reading practices concerned with traditional texts today include the non-traditional and nondenominational; ${ }^{5}$ while the Hebrew Bible as such has become the target of historicizing readings which take it as the foundation document of Israel as a modern nation state. ${ }^{6}$ The art of interpreting texts is furthermore prominently represented in the contributions of "secular" Jews to non-Jewish European culture, occasionally expressing themselves as readings of traditional Jewish texts, as in the case of Spinoza's Tractatus Theologico-Politicus and Freud's Der Mann Moses. ${ }^{7}$ However, it is in particular the notable readings which Jews have given to central non-Jewish texts of the European cultural tradition, which urges one to ask the strange question whether the mere practice of close reading - any text - signifies something Jewish. Does the intense, fine-grained, intricate and creative hermeneutic work which characterizes the output of prominently Jewish interpreters of modernity signify in and of itself a connection to Jewish

5 For example, "textual reasoning”; see Peter Ochs, "Introduction," in Textual Reasonings: Jewish Philosophy and Text Study at the End of the Twentieth Century, ed. Peter Ochs and Nancy Levene (Grand Rapids, MI: Eerdmans, 2003), 2-14; Steven Kepnes, Peter Ochs and Robert Gibbs, eds., Reasoning After Revelation: Dialogues in Postmodern Jewish Philosophy (Boulder, CO, Oxford: Westview Press, 1998); the Journal of Textual Reasoning (2002-) is found at http://jtr.lib.virginia.edu/ (accessed 13/07/15).

6 See e.g. David Aberbach, "Nationalism and the Hebrew Bible," Nations and Nationalism 11 (2005): 223-242; Thomas L. Thompson, "The Politics of Reading the Bible in Israel," Holy Land Studies: A Multidisciplinary Journal 7 (2008): 1-15.

7 See on these, for instance, Alex Samely, Spinozas Theorie der Religion (Würzburg: Königshausen and Neumann, 1993); Yosef H. Yerushalmi, Freud's Moses: Judaism Terminable and Interminable (New Haven, CT: Yale University Press, 1991); Jay Geller, Freud's Jewish Body: Mitigating Circumcisions (New York: Fordham, 2007). 
identity? Writer-readers such as Karl Kraus, Walter Benjamin, Theodor Adorno and Jacques Derrida do allude to their Jewish self-awareness or use vaguely Jewish motifs. Two examples that have become part of contemporary intellectual lore are Benjamin's reference to the Messianic in his Marxist reflections on time and history, which blurs the boundaries between the secular and the religious, the Jewish and non-Jewish; ${ }^{8}$ and the admiration of Jacques "Reb Dérissa" Derrida for the rabbinic tradition, ${ }^{9}$ expressed with a certain distance occasioned by a critical attitude and, presumably, a lack of technical reading competence. It is hardly a testable hypothesis to postulate that the meticulous interpretative guardianship of texts as such, whatever those texts might be, is a "Jewish" trait. But reading texts closely and strongly, being loyal to them even from a critical distance, or being loyal to the possibilities of language and to meaning as such, as in the case of Karl Kraus, could signify, could be a construction of, Jewish identity in Jewish intellectuals. ${ }^{10}$ Anecdotal evidence suggests that some selfdeclared Jews who are Jewish Studies academics do indeed at least in part con-

8 Walter Benjamin, “Theses on the Philosophy of History,” in Illuminations, trans. H. Zorn (London: Pimlico, 1999), 245 - 255. It may be worth pointing out that in his pre-Marxist work, for example his 1924 essay “Goethe’s Elective Affinities” (in Selected Writings: 1913-1926, volume 1, ed. Marcus Bullock and Michael W. Jennings [Cambridge, MA: Harvard University Press, 1996], 297 -360), Benjamin invoked what is patently not a specifically Jewish idea of God (nor Goethe's idea of God). It may be observed that he generally seems to use religiously charged language in a manner that gives the impression that he takes its meaningfulness for granted, without, however, otherwise echoing pre-Enlightenment or religiously committed attitudes. How this might be part of his philosophical project is explained in Peter Osborne and Charles Matthew, "Walter Benjamin," The Stanford Encyclopedia of Philosophy (Winter 2013 Edition), ed. Edward N. Zalta; http://plato.stanford.edu/archives/win2013/entries/benjamin/ (accessed 17/07/15) and see Brian Britt, Walter Benjamin and the Bible (reissue, Lewinston et al.: Edwin Mellen, 2003).

9 Jacques Derrida, "Ellipsis," in Writing and Difference, trans. Alan Bass (London: Routledge, 2001), 371-377; Susan A. Handelman, The Slayers of Moses: The Emergence of Rabbinic Interpretation in Modern Literary Theory (Albany, NY: SUNY, 1982), 169-171; see Edmund Jabès, The Book of Questions, vol. 1, trans. Rosmary Waldrop (Middletown, CT: Wesleyan University Press, 1991), 381.

10 In speaking in terms of "signifying" and "construction" here, I am using a constructivist device, perhaps ruse. These terms imply a fusing of "meaning for me" with "meaning intended by the author," that is, the deconstruction of the distinction of authorial intention from interpreter's perspective, which constructivism subscribes to. See below. Cp. also the claim by James I. Porter, which I encountered after this article was submitted to the editors, that Erich Auerbach's way of doing philology was self-consciously "Jewish," made in the "Introduction” to his Selected Essays of Erich Auerbach: Time, Literature, and History, ed. James I. Porter, trans. Jane O. Newman (Princeton, NJ: Princeton University Press, 2014), ix-xlv, here at xl-xlv; and also in his article, "Erich Auerbach and the Judaizing of Philology,” Critical Inquiry 35 (2008): 115 - 147; see Martin Vialon, "Erich Auerbachs verborgenes Judentum und sein Istanbuler Nachruf auf den Orientalisten Karl Süßheim,” Kalonymos 18, no. 2 (2015): 3-9. 
struct their Jewishness in this manner. More generally speaking, the discipline of Jewish Studies certainly does not stand outside historical processes of Jewish identity formation. ${ }^{11}$ One way for a contemporary Jew to construct her or his Jewish identity along non-traditional lines must surely be to become a Jewish Studies academic, perhaps in particular one working with Jewish texts. In any case, Jewish as well as non-Jewish practitioners of Jewish Studies unavoidably contribute a voice, namely that of their academic results, to contemporary Jewish discourses on the survival, adaptation and transformation of Judaism(s) in the modern world. An audience of Jews and non-Jews beyond the academy is affected by their findings, free to use them for constructing their self-view, their identity and their practice, often in unpredictable ways. Academics in certain branches of Jewish Studies sometimes set out deliberately to influence developments. This is as old as the academic discipline itself. For instance, Zunz's Die gottesdienstlichen Vorträge der Juden openly intervened in a debate on synagogue preaching in the vernacular. ${ }^{12}$ In the shape of Christian theology, the principle of a fusion of academic and religiously committed discourse is as old as Western universities. Following a similar model some Jewish Studies scholars choose to involve themselves in developing what might be called Jewish theologies, ${ }^{13}$ contribute to contemporary Jewish halakhah or Israeli state law, ${ }^{14}$ and articulate the spirituality of

11 Compare the following reflection pieces: Martin Goodman, "The Nature of Jewish Studies," in The Oxford Handbook of Jewish Studies, ed. Martin Goodman (Oxford: Oxford University Press, 2002), 1-13; Philip Alexander, "Neither Sacred Nor Secular," in Jewish Studies Quarterly 3 (1996): 301 -312; Peter Schäfer, "Judaistik und ihr Ort in der universitas litterarum heute: Einige Überlegungen zum Fach Judaistik in Deutschland," in “The Words of a Wise Man's Mouth are Gracious" (Qoh 10,12): Festschrift for Günter Stemberger on the Occasion of his $65^{\text {th }}$ Birthday, ed. Mauro Perani (Berlin: De Gruyter, 2005), 475-491; Dan Diner, "Jüdische Studien heute: Zwischen Beteiligung und Beobachtung," in Das Studium des Judentums und die jüdisch-christliche Begegnung, ed. Verena Lenzen (Göttingen: V\&R unipress, 2013), 41-48.

12 Leopold Zunz, Die gottesdienstlichen Vorträge der Juden, historisch entwickelt, introd. Rivka Kern-Ulmer (reprint, New York: Gorgias Press, 2003), x-xi; see also Kern-Ulmer's introduction, $\mathrm{xxv}^{\star}-\mathrm{xxvi}^{\star}$.

13 See for instance some of the works by Buber and Heschel, as well as Scholem and Fishbane; a book such as Jonathan Muffs, The Personhood of God: Biblical Theology, Human Faith and the Divine Image, ed. Yocheved H. Muffs (Woodstock, VT: Jewish Lights, 2005); or the scholars explicitly identified as having Jewish "sensitivities" (p. xiii) who contributed to The Jewish Annotated New Testament, ed. Amy-Jill Levine and Marc Zvi Brettler (Oxford: Oxford University Press, 2011).

14 There are numerous examples of this, perhaps the single most influential being the mishpat ivri approach of Menachem Elon and others; see e. g. his Jewish Law: History, Sources, Principles, 4 vols., trans. Bernard Auerbach and Melvin Sykes (Philadelphia: Jewish Publication Society, 2003). For a recent example, see the monographs of the Agunah Research Unit at Manchester University, Bernard S. Jackson, Agunah: The Manchester Analysis (Liverpool: Deborah Charles Publications, 2011); Yehu- 
Jewish prayers. ${ }^{15}$ In the UK and other countries, funding councils have begun to provide explicit incentives for research that can be argued to benefit society, including specific communities within society, for instance, Jewish ones. Scholarly discourse today appears to be significantly more tolerant, or at least more openly tolerant, than a few decades ago of strategies which pervasively fuse the detail of scholarly research with social, religious or other forms of engagement. At times, Jewish Studies scholars use the results of their research to champion Jewish cultural manifestations. Scholars seem more ready to update and validate Jewish sources, to present them as important to current issues and as providing life options; a trend now supported by prestigious university presses. The paradigm of a competition of narratives has entered academic practice, and at times certain theories of reading appear to be opportunistically invoked which declare neutrality to be impossible anyway. But Jewish Studies academics cannot form Jewishness appreciation societies without thereby corroding the tone, content and quality of Jewish Studies research. A related issue arises with regard to appointments to academic positions. If university decision-makers try to play it safe by appointing a scholar for a strictly academic post because of her or his vaunted or perceived Jewish ethnic identity, they undermine the subject area as well as equity. ${ }^{16}$ The effect of racial discrimination on the development of an academic field is certain to be detrimental. There are theoretical frameworks which claim that the cultural or ethnic self-identification of the scholar cannot, or even should not, be separated from her or his reading of the sources; more on this below. But even these cannot be used to justify discriminatory practices.

The field of Jewish Studies after the war also appears to carry a specific ethical responsibility. Many of its practitioners see themselves, rightly in my view, as standing under an obligation to lessen the possibility of another Holocaust,

dah Abel, Confronting 'Iggun (Liverpool: Deborah Charles Publications, 2011); Shoshana Knol, Agunah and Ideology (Liverpool: Deborah Charles Publications, 2011); Avishalom Westreich, TalmudBased Solutions to the Problem of the Agunah (Liverpool: Deborah Charles Publications, 2012); and Nechama Hadari, The Kosher Get: A Halakhic Story of Divorce (Liverpool: Deborah Charles Publications, 2012). These studies are available as free pdfs from: http://www.manchesterjewishstudies.org/agunah-research-unit/ (accessed 19/07/2015).

15 For an ostensibly non-denominational example, see My People's Prayer Book: Traditional Prayers, Modern Commentaries, vol. 7, Shabbat at Home, ed. Lawrence A. Hoffman (Woodstock, VT: Jewish Lights, 2004). It is advertised on the publisher's website as "rejuvenat[ing] Jewish worship in today's world” (http://www.jewishlights.com/page/product/PEOPLS, accessed 20/07/2015).

16 Cp. Aaron W. Hughes, The Study of Judaism: Authenticity, Identity, Scholarship (Albany, NY: SUNY, 2013); Michael Satlow, "Review of Hughes, Aaron W., The Study of Judaism," H-Judaic, H-Net Reviews, May 2014 (http://www.h-net.org/reviews/showrev.php?id=41235, accessed 30/ 03/2015). 
whether directed against Jews or non-Jews. This imperative makes itself felt by no means only in Jewish Studies. It is effective in all humanities disciplines, and to some extent beyond the humanities. I for one see the shadow of the Holocaust lying on contemporary signification and research tout court. But it is nevertheless the burden of Jewish Studies specifically to negotiate tensions that must at times arise between evidence-based contextualization of Jewish persons, actions and ideas on the one hand, and a temptation to produce apologetics on the other. On the whole, Jewish Studies has tended resolutely to favour the former over the latter, where such a choice arose, as is indeed necessary for its survival as a serious academic subject.

\section{The Temporal Investment in a Text before Reading It: The Case of a Talmud Commentary}

Let me make a first general observation on reading at this juncture, using as my illustration the medieval commentaries on the Babylonian Gemara which now adorn the margins of most Talmud editions. When commenting upon a passage in the Babylonian Gemara, a commentator will present a reading of the Gemara; that Gemara passage may well constitute in itself a reading of a Mishnah, quoted baraita (Mishnah-like statement) or biblical passage, and the first two of these may in turn be an implicit or explicit response to the same or another biblical passage. Even if that is not the case, the Talmud commentary may base itself on a simultaneous reading of passages from the Hebrew Bible, Mishnah and Gemara. This produces an extremely complex layering of hermeneutic relationships. Similar levels of complexity are routinely found in other works of the Jewish tradition, and in the works of many other cultures. I am using the example of such overtly complex texts here to make a more general point about reading. I want to consider the time commitment that needs to have taken place before a reading can even begin. Talmud commentaries are layered to the point where almost no "reading" can take place at all when someone reads them for the first time. Unless the reader has learned the contents and discourse of such a commentary, and the other texts it engages with, on earlier occasions of reading it or others, she or he will not be able to experience even a rudimentary understanding of the text's meaning. ${ }^{17}$

17 By "understanding" a text here I mean the ability to construct knowledge of the objects/ themes the text speaks of, not of merely the text's own structure. Constructing knowledge of the latter is always possible. Readers can gain a purely relational understanding of objects whose intrinsic nature escapes them entirely, by following clues for syntactic structures, cohe- 
But this reveals a crucial characteristic of all texts. Hermeneutically layered texts differ from apparently much simpler texts only in that they force upon the reader the insight that it is pointless to read them without heavy prior investment. Other types of texts, as well as texts received within a sufficiently narrow cultural context, do not force this insight, and yet are exactly the same in this respect, namely that they require heavy prior investment, which is usually hidden inside the labour of learning a "language," that is, a way of life, while growing up to become an acculturated adult and thereafter. Certain strands of Western culture have an ideal of textuality that tries to shape texts in such a way that they become self-sufficient. With antecedents in Graeco-Roman culture, this is the ideal of most scholarly writing today, and imparted to university students as a key component of their training. But this textual ideal and practice - never radically pursued except in certain kinds of philosophical texts - can distort the scholar's understanding of what constitutes a successful "text" when reading sources from pre-modern or non-European cultures. And even in everyday situations, readers constantly encounter texts which appear to be totally self-explanatory. Yet that impression is a contextual illusion, arising from the reader's intimate sharing of the cultural situation which the text reflects, without even being aware that there is something to share. A text gives the illusion of being self-explanatory, for example, because it embodies some social practice which the reader is entirely familiar with: a till receipt, a postcard from the seaside, a mobile phone text message, a popular novel, a newspaper article, and so forth. ${ }^{18}$ Another important group of apparently self-sufficient texts are those for whose contents the reader has already received a training of some sort. Consider, for example, the everyday reading matter of the lawyer, the administrator, the accountant, the nuclear physicist, the Buddhist monk. The large majority of texts anyone reads is embedded in some contemporary world and social practice in such a way that the text does not require any commentary whatsoever; furthermore, the text looks like it never will. For readers familiar with the context, it is initially puzzling to be asked to look for ways in which such a text would require commentary. This, that is, a total lack of conspicuousness, defines a successful text in purely functional communicative contexts. (Poetry and some other text types can work in the opposite way.) So that when historians face a text from another age which, for them, definitely requires commentary, they cannot know a priori whether in its time it already required one, because it was innovative in

sion and logical relations. For a striking demonstration of this ability, see Andy Johnson, Phonics and Word Identification Skills: Strategies for Teachers and Parents (Whitetail Publishing: Kindle, 2014), figure 1.2 (“Using Syntax to Create Meaning”).

18 With regard to understanding the biblical text, this is illustrated well in Marc Z. Brettler, How to Read the Jewish Bible (Oxford: Oxford University Press, 2007), 15-17. 
some way; or whether it did not require one, because it was entirely adapted to function in a contextual habitat, but a habitat that we do not share any more. Thus the useful question to ask is not, Is a commentary necessary? but, For whom is a commentary necessary? Even the most functional of texts will require commentary: from the parent to the child, or from the resident to the stranger. On the other hand, even the most recondite or technical text will require no commentary for a group of initiates, the limiting case being that this group has only one member, the author. The routine academic procedure of asking someone else to read the draft of an academic piece aims precisely at overcoming the over-familiarity of the author with her or his own text. And often the recommended revision aims to improve the text's ability to stand alone in diverse reader contexts, and does so by verbalizing some of its hitherto tacit background assumptions and adding them to the text itself.

So scholarly intuitions of textuality in general arise from two experiences which might be distorting: the perfect fit of most contemporary texts with their contextual niche, and the partial success of an ideal of self-sufficient and transparent academic compositions. Furthermore, the circumstances that make a text's meaning intelligible are usually precisely the ones that make it also relevant. My ability to "read" a text is tied to my interest in reading that particular text, that is, my context. This indicates, but also masks, the heavy prior investment in terms of time and effort which I have always already expended in understanding a text's subject matter, form, discourse, etc. - effectively starting from the day I began learning my first language as a child.

Scholars in the historical humanities learn to overcome any naïve perception of modern texts as self-explanatory through their training in the attitude and method of historical scholarship. Reading methodologies in the historical and critical humanities tend to assume that a text from the past, even if it happens to look self-explanatory, may well not be. So if a historically distant text reads as easy or familiar, then the logic of the historical method requires the scholar actively to reinstate the historical gulf, or to alienate the text from her- or himself. (There are echoes here of the character of poetic language which, in the important theory of the Russian formalists, is seen as estranging and de-automating language. ${ }^{19}$ ) One of the most common factors that alienate the text from the scholar automatically is its language, assuming it is not the scholar's own vernacular. The goal of an alienation or restoration of the historical gulf is to avoid anachronisms and other ahistorical ascriptions of meaning. And the way

19 See e.g. Winfried Nöth, Handbook of Semiotics (Bloomington, IN: Indiana University Press, 1995), 356. 
to achieve a bridging of the gulf, once properly constructed, is to expend labour in acquiring knowledge and build a reconstruction, that is, to invest much time. This time stands in parallel to the time the scholar invested in learning her everyday culture, by growing up and being acculturated into a community of sign users. The upshot is that the functional everyday text no less than the technical or the historically distant text, presupposes time spent prior to "reading" it for the first time, or requires re-reading it many times, before understanding it. In order to do justice to the competence of reading then, one ought to measure the time necessary for reading a text not only in terms of the hours spent when eyes and mind are finally in the presence of its wording. Rather, it ought to include the larger spans, usually measured in years, that a reader has invested before finding the text intelligible and interesting - that is, the years that make her or him want to read it in the first place. This time of socialization and learning is always invested in specific themes, objects and content, not only in a content-neutral skill called "literacy."

\section{The Empirical Study of Reading ${ }^{20}$}

Scholars who interpret primary and secondary sources are readers in an eminent sense. Their reading practice is subject both to pre-theoretical and to theoretical constraints. The theoretical constraints are conceptualized, negotiated and contested in generic and subject-specific methodologies and imparted to readers through the training they receive in school, undergraduate and graduate programmes. The historical-critical method is one example of such a methodology, as is deconstruction when practiced for academic purposes. But scholars are also pre-theoretical readers: embodied readers who cognize, as considered from the angle of psychology; and culturally contextualized readers, as considered in self-critical historical reflection. Acts of perception, which are bodily, underlie any understanding of text meaning, such as seeing the letters of a text on a page or screen, listening to the sounds of a spoken text, feeling with one's fingers the dots of Braille or touching the mouth, jawline and throat of a speaker. ${ }^{21}$ Read-

20 I am grateful to Michael A. Lyons, as leader of a Harvard workshop convened by Andy Teeter and Bill Tooman in October 2014, and to my doctoral student Marton Ribary, as assistant in a research project at Manchester University, for giving me important pointers in the large field of psychological studies of reading. I thank the convenors for inviting me to the workshop.

21 I here refer to the so-called Tadoma method; see e.g. Charlotte M. Reed, Nathaniel I. Durlach, Louis D. Braida and Martin C. Schultz, "Analytic Study of the Tadoma Method: Effects of Hand Position on Segmental Speech Perception," in Hand in Hand: Selected Reprints and An- 
ing also involves the accomplishment of mental "processing” and memory. These too have strong pre-theoretical and organic dimensions. Such aspects have been studied by empirical psychological methods since the late nineteenth century, and have produced a body of data which psychologists tend to see as providing an insight into reading processes that are universal or species-based..$^{22}$ Empirical reading research tends not to qualify its claims by saying: this is what reading is like in the twenty-first century, in the context of a modern culture, with a modern type of text contents and form, investigated through a certain methodology, etc. The empirical approaches aim to identify precisely those organic conditions, processes of sensible data reception and cognitive pathways that are not subject to historical or cultural variation. But even if one is inclined to question some of these assumptions, the results are relevant to the discourse on scholarship. For the contemporary scholar reads in the present age, and thus will be subject to pre-theoretical constraints of the kind which empirical reading research tries to discover. Reading today historical sources in order to produce, say, a critical edition of a Talmudic tractate or to interpret critically the memoirs of Glückel of Hameln, must share its pre-theoretical basics with reading a novel for entertainment, a shopping list for action, or a tabloid newspaper for gossip. Empirical reading research has a number of branches, allied in particular to the recently burgeoning field of the psychology of cognition. In what follows here, I will cite only some examples from this discipline that happen to be known to me, a tiny fraction of its literature. I therefore offer this outsider's glimpse of the discipline without claiming that the sample is representative. ${ }^{23}$ In addition to the acquisition of reading skills in children or adult learners, empirical reading research since the 1970s has been interested in: the visual scope and involuntary movements of the eye in sighted reading of written texts; ${ }^{24}$ the idea that the silent "sound" of a word sometimes or often mediates between visual word perception on the one hand and the retrieval of

notated Bibliography on Working with Students Who Are Deaf-Blind, ed. Kathleen M. Huebner, Jeanne G. Pricket, Therese R. Welch, and Elgar Joffee (New York: AFB Press, 1995), 28-36. 22 John C. Marshall, "The Cultural and Biological Context of Written Languages: Their Acquisition, Deployment and Breakdown," in Cognitive Approaches to Reading, ed. John R. Beech and Ann M. Colley (Chichester: Wiley \& Sons, 1987), 15-30.

23 An accessible account of the theoretical assumptions and practical implications of some reading research is the short book by Andy Johnson, Phonics and Word Identification Skills (n. 17); a recent synthesis for literary scholars in narrative studies is Anthony J. Sanford and Catherine Emmott, Mind, Brain and Narrative (Cambridge: Cambridge University Press, 2012).

24 Elizabeth R. Schotter, Randy Tran, and Keith Rayner, “Don’t Believe What You Read (Only Once): Comprehension Is Supported by Regressions During Reading," in Psychological Science 25 (2014): 1218-1226; see also Keith Rayner, ed., Eye Movements and Visual Cognition: Scene Perception and Reading (New York: Springer, 1992). 
the word's lexical meaning on the other, the so-called dual pathway; ${ }^{25}$ the recognition of words as wholes before, or independently of, letter recognition; ${ }^{26}$ the semantic "priming" of single word recognition by sentence meaning; ${ }^{27}$ the construction of sentences or of other units of meaning as influenced by overall text flow; ; $^{28}$ the link between brain regions and meaning cognition from reading, ${ }^{29}$ with data collected from persons with dyslexia; the potential role of text grammars, story grammars, ${ }^{30}$ and mental models more generally, as readers make their linear progress through a text; the contribution of "world knowledge" to understanding a text; ${ }^{31}$ the role which the recollection of earlier text parts and inferences to later text parts play, ${ }^{32}$ and such processes taken as a paradigm for cognition more

25 Andrew W. Ellis and Andrew W. Young, "Reading: And a Composite Model for Word Recognition and Production," in Human Cognitive Neuropsychology: A Textbook with Readings, ed. Andrew W. Ellis and Andrew W. Young (Hove, East Sussex: Psychology Press, 1996), 191-238; Anthony Esgate and David Groome, An Introduction to Applied Cognitive Psychology (Hove, New York: Psychology Press, 2005).

26 Charles Perfetti and Joseph Stafura, "Word Knowledge in a Theory of Reading Comprehension," Scientific Studies of Reading 18 (2014): 22-37.

27 This research shows a difference in timed reader tasks between processing a sentence like "The sky is blue" (a congruous sentence ending) and "The sky is fat" (an incongruous ending); see Enrico Schulz, Urs Maurer, Sanne van der Mark, Kerstin Bucher, Silvia Brem, Ernst Martin, and Daniel Brandeis, "Impaired Semantic Processing During Sentence Reading in Children with Dyslexia: Combined fMRI and ERP Evidence,” in NeuroImage 41 (2008): 153-168.

28 Daniel Grodner, Edward Gibson, and Duane Watson, "The Influence of Contextual Contrast on Syntactic Processing: Evidence for Strong-Interaction in Sentence Comprehension," in Cognition 95 (2005): 275-296.

29 Charles A. Perfetti and Gwen A. Frishkoff, "The Neural Bases of Text and Discourse Processing," in Handbook of the Neuroscience of Language, ed. Brigitte Stemmer and Harry A. Whitaker (London: Academic Press, 2008), 165 -174; Sung-il Kim, Misun Yoon, Wonsik Kim, Sunyoung Lee, and Eunjoo Kang, "Neural Correlates of Bridging Inferences and Coherence," Journal of Psycholinguistic Research 41 (2012): 311 -321; Schulz et al., "Impaired Semantic Processing” (see n. 28).

30 David E. Rumelhart, "Notes on a Schema for Stories," in Representation and Understanding, ed. Daniel G. Bobrow and Allen M. Collins (New York: Academic Press, 1975), 211-236.

31 Arthur Graesser, Jonathan M. Golding, and Debra L. Long, "Narrative Representation and Comprehension," in Handbook of Reading Research, vol. 2, ed. Rebecca Barr, P. David Pearson, Michael L. Kamil, and Peter B. Mosenthal (Mahwah, NJ: Erlbaum Associates, 1996), 171-205, here at 188 , and other papers in the same volume.

32 Teun A. van Dijk and Walter Kintsch, Strategies of Discourse Comprehension (New York, London: Academic Press, 1983); Timothy P. McNamara, Diana L. Miller, and John D. Bansford, "Mental Models in Reading Comprehension," in Handbook of Reading Research, vol. 2, ed. Barr et al., 490-511. 
generally; ${ }^{33}$ and the production of coherence as a key criterion for the "success" of reading. ${ }^{34}$ Terms taken from the field of computing are pervasive. Some psychologists employ them in a loose, metaphorical manner, but others explain mental processes involved in reading as more directly related to processes in computing. ${ }^{35}$ Apart from data arising from the study of developmental and acquired dyslexias, ${ }^{36}$ the most common empirical methods in this research are observations of eye movements and measurements of the speed with which a test subject can recognize a single word, or recollect a text's wording or content; also the durability of such memories, tending to show that recollection of the content is significantly better than that of the wording. The speed of recollection or processing is usually considered as allowing the distinction of more basic or "automatic" processes of understanding, which are faster, from those of more complex or higher-level understanding. Another, less common, type of empirical data arises from asking test subjects to "think aloud" while reading a text. ${ }^{37}$ The usefulness of results gained in empirical reading research for a self-understanding of the historical methodology is limited by a number of factors. Thus the texts used in experiments tend to be artificially constructed, short, narrative and presented without context. Here is an example of the sometimes extreme brevity of text samples used, in this case in research into text coherence: ${ }^{38}$

33 Beech and Colley, Cognitive Approaches to Reading; Walter Kintsch, Comprehension: A Paradigm for Cognition (Cambridge: Cambridge University Press, 1998).

34 Robert F. Lorch, Jr. and Edward J. O’Brien, eds., Sources of Coherence in Reading (Hillsdale, NJ: Lawrence Erlbaum, 1995); Paul van den Broek and Mary Gustafson, "Comprehension and Memory for Texts: Three Generations of Reading Research," in Narrative Comprehension, Causality and Coherence: Essays in Honor of Tom Trabasso, ed. Susan R. Goldman, Arthur C. Graesser and Paul van den Broek (Mahwah, NJ: Erlbaum, 1999), 15-34.

35 Evan Chen, Edward Gibson, and Florian Wolf, "Online Syntactic Storage Costs in Sentence Comprehension," in Journal of Memory and Language 52 (2005): 144-169; and the observations by Christopher M. Aanstoos, "A Critique of the Computational Model of Thought: The Contribution of Merleau-Ponty,” in Journal of Phenomenological Psychology 18 (1987): 187-200. 36 H. Branch Coslett, "Acquired Dyslexia," in Patient-Based Approaches to Cognitive Neuroscience, ed. Martha J. Farah, and Todd E. Feinberg (Cambridge, MA: MIT Press, 2000), 235-246. 37 Virginia Clinton, Sarah E. Carlson, and Ben Seipel, "Linguistic Markers of Inference Generation While Reading," in Journal of Psycholinguistic Research, doi: 10.1007/s10936-0159360-8 (in press); see also Alec W. McHoul, Telling How Texts Talk: Essays on Reading and Ethnomethodology (London: Routledge and Kegan Paul, 1982).

38 From Sung-il Kim et al., "Neural Correlates," 315. 
(1) Sample story with Strong Coherence:

A widow worried about her weight.

The widow bought a jump rope.

The widow skipped the jump rope every morning.

(2) Sample story with Weak Coherence:

A widow worried about her weight.

The widow bought a jump rope.

The widow measured her waist size with the jump rope.

(3) Sample story with coherence "Control" 39

A widow worried as heavy climb.

The widow weighted chilled buy.

The widow rope is abundant with salty people.

Text length and complexity separate experimental test samples such as this one from a vast number of modern everyday texts and, more importantly for our topic, from the most common text types that constitute the primary evidence of the historian. Nevertheless, taking account of empirical research into reading is likely to be useful for developing the self-understanding of the modern humanities. A sustained interpretation of the findings of psychology from the perspective of humanities methodology is an urgent desideratum, although the book by Sanford and Emmott mentioned earlier makes an excellent start with that for narratives. My own current impression could be summarised as follows. It is suggestive to me that, as the research methodologies and topics have matured, the methods increasingly assume that reading is an integrative skill, and that the "higher-level" processes, that is, the experiences of verbal meanings, are crucial for the "lower-level" routines also. The former would include such notions as world knowledge, anticipation, and memory ${ }^{40}$ I furthermore receive the impression that attempts to tie specific organic functions or brain regions to a reader's ability to construct abstract meaning, which is what all understanding from reading must be to begin with, are nowadays not necessarily based on a view that reduces experiences of meaningfulness to organic process-

39 Sung-il Kim et al., "Neural Correlates," 314, explain the control materials as "constructed as grammatically correct [sic] but nonsensical sentences to prevent any meaningful sentential processing."

40 See as one of many examples of research tracing memory activity in brain regions, Aidan J. Horner, James A. Bisby, Daniel Bush, Wen-Jing Lin, and Neil Burgess, "Evidence for Holistic Episodic Recollection Via Hippocampal Pattern Completion," in Nature Communications 6:7462 (2015): 115, doi: 10.1038/ncomms8462; see also Jonathan Webb, "Peeking into the Brain's Filing System," BBC Website 2015 (http://www.bbc.co.uk/news/science-environment-33380677, accessed 10/07/ 2015); for the role of functional Magnetic Resonance Imaging (fMRI) see Sanford and Emmott, 272. 
es. That is obviously important for a possible future cross-fertilization of empirical reading research and text research in the humanities.

\section{Coherence}

A central topic in the research on Jewish sources has been the question of text unity. Implicit or explicit responses to biblical contradictions and repetitions abound in the Jewish hermeneutic tradition of antiquity, from rewritten Scripture to rabbinic Midrash. Responses to contradictions and repetitions were also crucial in the development of early modern post-traditional methods for reading the Bible, in particular biblical criticism as conceived by Spinoza ${ }^{41}$ and others. In their turn, the pioneers of the Wissenschaft des Judentums studied post-biblical hermeneutic and other ancient sources "critically," and this practice continues to flourish today. The critical methodology, most highly developed in biblical studies, separates layers of text growth from an original text core, allocating the core and layers as such to different times, places and authors. These times, places and authors are therefore often postulates arising from text structures, without necessarily drawing on any external evidence of compositional or redactional activity. Where different versions of the same book are extant, for example in the Septuagint and in the Masoretic Text of the Hebrew Bible, their synchronic comparison provides prima facie evidence of text changes. But the discovery of textual sources, traditions or redactional layers - such as E, J, P and D in biblical studies - is not dependent on, and often not directly supported by, extant evidence of text variants or recensions. Rather, it arises from diachronic, forensic readings, in particular the licence to go against the grain of the self-presentation of the text as a continuum. The text is read with a view to discovering its seams and traces of interventions. Many products of scholarship on biblical texts (e.g. Gen 1-2) follow this methodology, and it is also extremely common in the research into extra-canonical, post-biblical and rabbinic sources. Phenomena of incoherence play a central role in such approaches, which prompts the following reflections. In order to be able to recognize phenomena of incoherence, and to derive from them the inference that a text contains secondary changes, one relies on standards or expectations of coherence. It is these expectations which the text "disappoints" in the first instance, and which are restored through the reconstruction of hypothetical sources and layers, that is, of alternative text boundaries. Much analysis of texts in the study of the Hebrew Bible and post-biblical

41 See n. 7 above. 
anonymous and pseudepigraphic works is called forth by the disappointment of modern scholarly coherence expectations. In their light scholars take the texts to reveal their composite nature ${ }^{42}$ their collective production ${ }^{43}$ or their dependency on oral traditions. The phenomena which disappoint the scholarly reader's expectation of coherence, and thereby serve as internal evidence supporting such hypotheses, include stylistic breaks, narrative gaps, propositional contradictions, unmotivated discontinuities, unexplained repetitions, and even different thematic-narrative emphases as expressive of ideological differences. The forensic diachronic methodology at work here must assume that the standards of coherence of the modern reader are the same as those of the ancient text maker. Otherwise incoherence phenomena could not be interpreted as inadvertent clues to a secondary interference with the original shape of the text. This assumption in turn must be based on one of two beliefs. Either one holds that there is a fundamental cultural resemblance, for example by way of an historical continuity of text expectations, between Jewish antiquity and modern Western scholarly culture; or one believes that the modern-scholarly standards of coherence are universal. Otherwise, that is, if Jewish text makers and readers had different assumptions or habits of text coherence, they may not have seen as incoherent the phenomena which we read as incoherent, and thus created texts that contained them from the start. Texts which contained these phenomena from the start as deliberate choices of composition or habits of a culture would render the forensic reading practice of the historical-critical approach largely inapplicable. So specific assumptions on what constitutes a coherent text are crucial to this scholarship. However, a very different understanding of phenomena of incoher-

42 See e.g. Philip R. Davies, IQM, The War Scroll from Qumran: Its Structure and History (Rome: Biblical Institute Press, 1977); James E. Miller, "The Redaction of Tobit and the Genesis Apocryphon," Journal for the Study of the Pseudepigrapha 8 (1991): 53-61. These two are meant to stand in for a very large number of publications assuming various degrees of secondary growth in most ancient Jewish texts. Some of the relevant literature is to be found in the bibliography sections of the profiles that make up the open access Database for the Analysis of Anonymous and Pseudepigraphic Jewish Texts of Antiquity, ed. Alex Samely, Rocco Bernasconi, Philip Alexander, and Robert Hayward, 2012 (http://literarydatabase.humanities.manchester.ac.uk/, accessed 26/03/2015). The following features documented for individual texts in the Database are interpreted as indicating secondary text growth in diachronic analysis: 2.3, 4.14, 4.15, 5.1, 5.7.5, 6.7, 6.12, 9.4.1, 9.8, 9.11, 10.1 and 10.2. See further the overview of phenomena of incoherence in Alex Samely, Philip Alexander, Rocco Bernasconi, Robert Hayward, Profiling Jewish Literature in Antiquity: An Inventory, from Second Temple Texts to the Talmuds (Oxford: Oxford University Press, 2013), $327-328$.

43 Martin Jaffee, "Rabbinic Authorship as a Collective Enterprise," in The Cambridge Companion to the Talmud and Rabbinic Literature, ed. Charlotte E. Fonrobert and Martin Jaffee (Cambridge: Cambridge University Press, 2007), 17-37. 
ence in texts has emerged in the second half of the twentieth century. The effect of this approach has been to divide academic practice in the humanities, Jewish Studies included. Nowadays scholars working on the same primary evidence but with divergent methodologies can come to results that seem mutually useless and alien. And this is partly due to a fundamental difference in interpreting textual in/coherence, bound up with other assumptions to which I now turn.

\section{Un/Stable Text Meaning}

The new academic reading practices which have emerged since the mid-1960s are known by various and often overlapping labels. I will use the adjective "constructivist” as my main umbrella term. I mean by this shared ideas in cultural studies, cultural theory, post-modernism, post-structuralism, intertextuality, "death of the author," and deconstruction. Additionally, these approaches often adopt psychoanalytical and/or materialist strategies which, predating post-modernism, already read a text against the grain, against the author's assumed intention. New academic disciplines, such as post-colonial, translation, gender and queer studies, have sprung up, together with new forms of literary studies, visual studies, and scholarship on the body. I will try to provide an interpretation of what I see as the key aspects and claims of the constructivist approach. A central role plays the rejection of the idea that a text has a stable meaning or, for that matter, stable phenomena of incoherence. This incorporates the structuralist insight that the link between signifier and signified is arbitrary, leading to the view that linguistic signification is in all respects historically malleable. This is then often paired with the assumption that a reader's cognition of a text is wholly mediated by her or his society, as the repository of all language-related learning. The reader is not taken to be a self-transparent subject who constructs a text's meaning first and foremost as an individual. Rather she is taken to be opaque to herself; hence the easy alliance with Marxist materialism and Freudian/Lacanian psychoanalysis. The subjectivity of readers arises from how their culture/society constructs individuality, gender, ethnicity, autonomy - the subject is not prior to society. Accordingly, texts "have" meaning only in relation to the cultural, historical and to some extent biographical limits of a specific readerly context - that is, strictly speaking unknowable limits. Text meaning is thereby wholly historicised, and academic work must consequently be concerned with the historical and present conditions of the readings texts receive, rather than with a reconstruction of their original and authorial meaning. That authorial meaning is taken never to have existed, since no author can be construed as an autonomous subject, any more than a reader. The "a priori" 
of any text is always a particular historical a priori, that is, a changing, contingent and yet inescapably limiting a priori, not the universal a priori of reason or of human consciousness. ${ }^{44}$ How does this affect the presence of apparent phenomena of incoherence in a text? Some branches of the approach read the text against the grain by deconstructing conceptual oppositions which the text relies on and thereby point to inconsistencies grounded in the Western tradition of metaphysical thought, that is, the search for propositional consistency. In other branches of the constructivist approach the tensions caused by power inequalities in any historical culture, including those of the author, later readers and the present reader, are reconstructed from the text, partly again through inconsistencies. But inconsistencies are not "in" the text; they are constructions by readers, as is their absence. These ideas were largely developed in engagement with the literary, scientific and philosophical texts of modern or early modern Europe, thus mostly for single-authored works whose unity of production does not stand in question in the way in which it does for many pre-modern or non-European texts. In constructivist approaches the in/coherence of a text has a very different status from the historical-critical discovery of strata of composition and redaction. In/coherence ceases to be an argument for or against text unity, for or against secondary text interventions, ultimately because all meaning discovered in a text is by definition "secondary."

Many scholars have enthusiastically embraced some or all of the aspects here summarised. Important practical corollaries of these ideas, useful to many Jewish Studies academics, include the notion that objects other than texts can be read, and therefore that non-texts do not constitute marginal evidence in the academy; that texts themselves also have a material existence, a body, which contributes to the way embodied readers construct their meaning; that texts can play a central role in the formation of the identities of groups; and that the field of Jewish Studies does not have a "core" and "periphery," nor Jewishness an "essence.” Research on Jewish culture in all periods has bene-

44 This denial of the ultimate autonomy of the subject in Foucault and others is therefore not itself to be historicised; it is a universal assumption. The approach must, it seems, deny the possibility that at some point in the past humans were autonomous subjects. Thus the approach appears to rely on at least one absolute truth that must not be subjected to the historicising move itself. Perhaps it is partly in order to avoid the manifest inconsistency of having such an absolute truth that universal descriptive claims of the kind I am using here are usually avoided. Cp. Foucault's hypothetical language in $\mathrm{n} .52$ below, and the comment by Hayden White, “... his [Foucault's] thought comes clothed in a rhetoric apparently designed to frustrate summary, paraphrase, economical quotation for illustrative purposes, or translation into traditional critical terminology;" The Content of the Form: Narrative Discourse and Historical Representation (Baltimore, ML: Johns Hopkins University Press, 1987), 104. 
fited from these trends. In 2013 a new editorial team of the AJS Review summed up the changed situation as follows:

We are witnessing new approaches to traditional fields such as rabbinics and Jewish history, as well as the integration of entirely new fields such as media studies, music, art history, visual culture, and more. As editors, we want to include the best work in all of these approaches and fields in the journal. ${ }^{45}$

For the medieval and modern periods, a considerable number of scholars have effectively fused the achievements of philology and non-constructivist historiography with aspects of the new approaches to reading. ${ }^{46}$ This is not happening to the same extent in the study of Jewish antiquity, perhaps because contextual evidence for the production of texts is so scarce; there is not much cross-fertilization of the two attitudes. But syntheses of old and new reading methods raise some conceptual issues. Scholars who self-consciously reject a stable core of meaning in texts tend to view all later readings of earlier texts as updatings. This includes their own readings, as well as that of colleagues working with the historical-critical or any other conventional academic toolbox. In this view, the reader's formation of a text's meaning is never a reconstruction of some mythical "original" text meaning. Therefore, from the point of view of the postulate of original meaning, all interpretations, including the ones that try hardest to reach it by some scientific method, must be described as "de-formations," but only for as long as one does not realize that there are no other ways to read but de-formations. All readers must be seen as equally inescapably situated in their own societal meaning structures, those of a particular present. Attempts to create objective reconstructions of the past, or "how it really was," thus have to appear naïve. What can be done instead includes the following options: (i) to offer a critique of earlier scholarly and other readings of primary sources, in which these interpretations are contextualized as historically limited and expressive of tensions, con-

45 Christine Hayes and Magda Teter, "Editorial: Statement from the Incoming Editors," AJS Review 36 (2010): 185.

46 See, as one of a number of examples, Miri Rubin's approach to medieval culture in her Gentile Tales: The Narrative Assault on Late Medieval Jews (Philadelphia, PA: University of Pennsylvania Press, 2004); Rubin speaks of the importance of access to a rich context for doing work on representations as follows: "One truth which emerges from confronting the host desecration accusation as narrative is that even the most pervasive representations - visual or textual - can only be understood fully when observed embedded within the contexts that accredited them and gave them meaning." Then, turning to her method, she continues: "Yet it is impossible to deal with historically specific events without addressing the textual quality of almost all remaining traces.” (p. 2) 
tradictions or power relations of their time, but still affecting the present; (ii) to trace out the meanings that the text does not foreground or admit to, but which show up the cultural assumptions and tensions on which it is based, from the present perspective; and (iii) to investigate whether the very terms and assumptions by which today's scholarship goes about the business of reading a primary source owe their existence and meaningfulness partly to the historical-cultural effect of that very source or similar ones. ${ }^{47}$ The last point amounts to saying that the modern reader must learn to see, in a historical text that she reads, traces of the history of the very pair of eyes by which she reads it. These and similar constructivist tasks can lead to academic studies that richly contextualize and document the historical background of a source, thereby also approaching the goals of non-constructivist historiography. ${ }^{48}$ On the other hand, many contemporary historians who are not constructivists are happy to concur in the implied scepticism of constructivists by accepting that the source's original meaning that they postulate across the historical gulf is ultimately elusive. But this generic acceptance has no impact on the concrete procedures by which they read the sources. The challenge from constructivist thought is more fundamental than can be met merely by a prefatory admission of uncertainty. The two opposing approaches really imply divergent theories of meaning and of human consciousness, influencing the basic techniques of reading and therefore the detailed reading results. But while mutual comprehension does not exactly prevail between the two camps, non-constructivist scholarship has benefitted directly from the existence of constructivist approaches; that the reverse is true goes without saying. Thus non-constructivist Jewish Studies scholars nowadays

47 Gadamer's notion of Wirkungsgeschichte (“effective-history”) is relevant here, as are more recent conceptualizations of this kind in cultural studies and in a Foucauldian vein. What Wirkungsgeschichte actually means for Gadamer is often misunderstood. "Es wird also nicht gefordert, daß man die Wirkungsgeschichte als eine neue selbständige Hilfsdisziplin der Geisteswissenschaften entwickeln solle, sondern daß man sich selbst richtiger verstehen lerne und anerkenne, daß in allem Verstehen, ob man sich dessen ausdrücklich bewußt ist oder nicht, die Wirkung dieser Wirkungsgeschichte am Werke ist.” Hans-Georg Gadamer, Wahrheit und Methode: Grundzüge einer philosophischen Hermeneutik, $7^{\text {th }}$ ed. (Tübingen: Mohr Siebeck, 2010), 306; "We are not saying, then, that history of effect must be developed as a new independent discipline ancillary to the human sciences, but that we should learn to understand ourselves better and recognize that in all understanding, whether we are expressly aware of it or not, the efficacy of history [of effect, A. S.] is at work." Truth and Method, trans. and revised by Joel Weinsheimer and Donald G. Marshall (London, New York: Bloomsbury Academic, 2013), 312; cp. the translator's preface, xiv- $x v$.

48 I find this possibility exemplified by two very different works, namely Admiel Kosman, Gender and Dialogue in the Rabbinic Prism, trans. Edward Levin (Berlin, Boston: De Gruyter, 2012) and Jay Geller, On Freud's Jewish Body. 
routinely examine the dialectical relationship between the representation of the Jew as the "Other" of Christians, Muslims, Germans or Britons, on the one hand, and the construction of Jewish, Christian, Muslim, German or British self-perception on the other - treating both as "representations." 49 This way of looking at it has asserted itself alongside the rise of constructivist approaches, and its philosophical justification, insofar as any is sought, lies in constructivist theory. Constructivist thought has more generally helped to bring into the mainstream of certain disciplines, such as European history, Jewish sources that used to be seen as marginal to the study of the majority cultures. It is also clear that Jewish Studies, various branches of which naturally straddle discipline boundaries, have benefited from the radical inter-disciplinarity of some of the constructivist approaches. For the constructivist engagement with an historical object will often construct that object as transgressing the limits of any one of the academic fields that would "objectively" study it.

\section{Reading and Consciousness}

"Cultural Theory," "Deconstruction," "Intertextuality" - these are battle cries in a philosophical clash of views on the nature of subjectivity. The constructivist position indicated by them is, in a nutshell, that meaning, while being experienced as proper to an individual self, is nothing of the sort, but is fundamentally socially mediated. Contrary to appearances, the subject or self is not, as much earlier philosophy had argued, self-transparent. Modern thinkers of human unfreedom such as Nietzsche, Marx and Freud, are indirectly also precursors to this stance. ${ }^{50}$ Nor is the notion of "the subject" accepted, as meaning some kind of substance-like personhood with a core - the cognizing self - that would be universal or stable across the construction differences of gender, race, and economic or historical situation. How meaning is produced when one reads a text does then not only depend on knowledge of the language, a competence already so-

49 Miri Rubin puts it very clearly when stating, "The host desecration tale was told by Christians, to Christians, to make Christians act and redefine that which made them Christian. That they could do so most easily and rewardingly through thinking about Jews, and acting upon Jewish bodies, books, dwellings, is proof of the intimacy which prevailed between the two groups," Gentile Tales, 6.

50 See Michel Foucault, "What is an Author?," in Essential Works of Foucault 1954-1984, vol. 2, Aesthetics, Method, and Epistemology, ed. James D. Faubion (New York: New Press, 1998), $205-222$. 
cially defined. ${ }^{51}$ It also depends on the reader's acquaintance with many other texts and cultural products. Meaning is produced within a matrix in which "ultimate" meaning is always deferred, does therefore not come to rest in the individual; it is made and unmade to the beat of a societal rather than an individual rhythm; it is not transcendent or "logocentric," but historical; and while subjectively experienced as being "in" the text and "in" the reader, it is in fact distributed in ever-changing, post-human spaces of discourse. So meaning is not borne by a new, collective subject, something like Hegel's Spirit. Rather, it is de-centred, historically contingent, and amorphous: culture qua society, or "discourse." 52 The individual, whose ontology and boundaries are open to question or to "construction," is in touch with this distributed, decentred meaning through what in the older model of the subject was the "unconscious," rather than merely through consciousness. The position draws on several centuries of Western visual art, literature, philosophy and psychology declaring the opaqueness of human beings to themselves, from the time of Spinoza's theory of the affects to Freud and post-Freudian theories of desire. It also responds to the seemingly radical difference of human cultures from one another, as viewed after trust in the idea of progress and universal history has disappeared. Consequently one must see the ways in which readers connect meanings to other meanings, both within the text and without, as associative rather than logical, evocative rather than conceptual, figurative rather than controlled. The meaning of a text is then not the stable counterpoint of something stable, namely the reader as a subject. Rather, reader persons are ultimately communally mediated (self-)constructions, no less than text meanings are.

What are the alternatives to this philosophy of a-subjectivity, sometimes also called post-humanism? There are several alternatives, but I am most interested in exploring that of phenomenology. Phenomenology claims that subjective consciousness as actually experienced by the reflecting person unavoidably takes priority over other types of cognition (such as a belief in the distributed nature of meaning), despite being available to introspection only via reflection itself. The following would be the main topics in a phenomenological view of reading, much condensed and speaking provisionally:

51 See for instance, Jonathan Culler, Saussure (Glasgow: Fontana, 1976), 51-52. This also chimes with certain philosophical positions, such as the later Wittgenstein's.

52 Foucault says of the proper methodology for understanding the "subject" that experiences or creates meaning: "It is a matter of depriving the subject (or its substitute) of its role as originator, and of analyzing the subject as a variable and complex function of discourse"; "What is an Author?," 221. 
(1) Reading is a perception-based experience constituted, on the one hand, from acts of consciousness and, on the other, from a pre-verbal "passivity" of consciousness, that is, the ongoing creation of a horizon of meaning for those acts of consciousness. A reader's encounter with meanings in a text is not dissimilar to other encounters with meaningfulness, starting with the perception of non-verbal objects, and thus experience of a "world" more generally.

(2) Like all experience then, the encounter with the meaning of verbal entities in texts is profoundly temporal. Not only is constructing a text's meaning embedded in the reader's construction of her or his own temporality, it is also temporally extended in itself, unless the text is extremely brief. Understanding the text's meaning is an activity that is experienced as impossible to perform in one single act of synthesis, but as arising from an agglutination of temporally discrete and sequential meanings. The discrete meanings are those of smaller units, in most cases the sentence. The text's meaning is then built up from experiencing the meaning of many sentences (or some other shorter units) one after the other, and thus from living through temporal separation and scattering. The many acts of understanding single sentences cannot be reduced to one instantaneous meaning without losing much of the detail. A summary sentence, although it can be created or understood in a single act of synthesis, cannot present the richness of detail that the separate units hold and that are experienced in reading. That richness is thus not available to the kind of integration by which words are integrated in the meaning of one sentence.

(3) If one investigates how meaning integration happens for a text, one discovers, following Husserl, that it depends on two involuntary aspects of consciousness: the ongoing non-deliberate anticipation of what comes next, and the ongoing non-deliberate holdingon to what went before.

Taken together, these points define what makes a text coherent or incoherent: incoherence first arises when the meaning of the next sentence in the text conflicts with a non-deliberate anticipation created on the basis of earlier sentences; coherence is maintained when this is not the case. Husserl's expression for the interlocking of non-deliberate anticipation and remembrance is "passive synthesis," which he distinguishes from specific acts of synthesis, such as the actualization of a sentence meaning. Further, in his parlance, retention is the term for the non-deliberate holding-on to past meaning and protention for the non-deliberate anticipation of future meaning experiences. ${ }^{53}$ This then provides one possible counter-position to the constructivist approach outlined earlier. ${ }^{54}$ Arguably this

53 The key works are Edmund Husserl, Analyses Concerning Passive and Active Synthesis: Lectures on Transcendental Logic, trans. Anthony J. Steinbock (Dodrecht: Kluwer, 2001) and, Experience and Judgment, ed. Ludwig Landgrebe, trans. Spencer Churchill (Evanston, IL: Northwestern University Press, 1973).

54 The above sketch is a significant development from my earlier positions in: "Observations on the Activity of Reading," in Husserl and the Logic of Experience, ed. Gary Banham (Basingstoke, New York: Palgrave Macmillan, 2005), 131-159; see also "Holding on to Meaning. Text Coherence, Reading and Rereading," in Hebrew Bible and Ancient Israel (forthcoming 2017). For more general 
conceptualization suggests that the reader's construction of text meaning, arising as it does from the encounter with one sentence after another, is biased towards making them cohere..$^{55}$ For passive synthesis more generally provides the basis for a subject synthesizing its own identity through time, making it possible for deliberative reflection or deliberate recollection to encounter a self that is continuous from one moment to the next. Thus consciousness, in particular its "passive" dimension, appears to create first and foremost links. It is within a matrix of links that non-links are capable of appearing, not vice versa. Non-links between moments of experience are surprises, leading to the discovery of earlier or present errors or, in the case of text reading, to the experience that the text disappoints expectations. It therefore appears that consciousness mechanisms would favour constructing "non-surprising" links between the discrete experiences of sentence meanings over surprising links, or interruptions. The reason for this would be that links are a more direct way to confirm the self's continuity than surprises, even though the latter also confirm that self unless they overwhelm in some manner the underlying continuity. The reader would favour continuity between sentence meanings, because of a tendency to see primarily that which confirms expectations. ${ }^{56}$ This applies to texts in particular if the reading takes place in a relaxed default mode. By contrast, reading a text "closely" could then be defined as having a project to seek out further, additional links deliberately, thereby also increasing the chances of discovering non-links. A close reading thus can become a

background on the phenomenology of reading, see Samuel IJsseling, "Lesen und Schreiben: Husserl über Texte,” in Distanz und Nähe: Reflexionen und Analysen zur Kunst der Gegenwart, ed. Petra Jaeger and Rudolf Lüthe (Würzburg: Königshausen und Neumann, 1983), 173-190; Wolfgang Iser, The Act of Reading: A Theory of Aesthetic Response (London, Henley: Routledge and Kegan Paul, 1978); Der Implizite Leser, $3^{\text {rd }}$ ed. (Munich: Fink, 1994); Roman Ingarden, Das literarische Kunstwerk, $2^{\text {nd }}$ ed. (Tübingen: Max Niemeyer, 1960) and The Cognition of the Literary Work of Art, trans. R. A. Crowley and K. R. Olson (Evanston, IL: Northwestern University Press, 1973); also Detlef Thiel, Über die Genese philosophischer Texte: Studien zu Jacques Derrida (Freiburg: Alber, 1990); for a different approach, poised between empirical psychology, sociology and phenomenology, see McHoul, Telling How Texts Talk; James L. Heap, “Toward a Phenomenology of Reading,” Joumal of Phenomenological Psychology 8 (1977): 104-115.

55 Such a bias is in fact often assumed, though rarely explained, in literary and related studies, as well as in the psychological research summarised in an earlier section above. See e.g. David Birch, Language, Literature and Critical Practice: Ways of Analysing Text (London: Routledge, 1989), 22-23, 35-37 and passim.

56 The same underlying mechanism could perhaps also be linked to the phenomenon of "confirmation bias"; see e.g. Joshua Klayman, "Varieties of Confirmation Bias," The Psychology of Learning and Motivation 32 (1995): 385-418; and more recently, Daniel Kahneman, Thinking, Fast and Slow (London: Penguin, 2012), 80-81. The book is of some interest for the psychology of reading also. 
critical reading, in that the coherence of the text becomes an object of deliberate probing, becomes problematical. Yet phenomena of incoherence make their appearance within an overall enterprise of coherence. They become consciously recognized as such first and foremost because they disappoint non-deliberate expectations, even though an active, critical reading can search for incoherence deliberately. If passive synthesis indeed gives the discovery of coherence priority over incoherence, then the constructivist view of the in/coherence of texts outlined above is flawed. But even the phenomenological view does not accept that constructing a text's meaning is self-transparent to the reader. It involves passive synthesis, which is non-deliberate. The reader is envisaged to be no more deliberately guiding all separate mental processes that are required than $\mathrm{s} /$ he is guiding all the separate muscular movements necessary for stretching out an arm. ${ }^{57}$ Yet scholars concerned with historical texts often speak as if text meaning were available in all its detail at a glance, as if the reasons for having reached a certain understanding could be made exhaustively transparent and spelled out in summary form. Even branches of scholarship in which lip service is routinely paid to the results of reading being merely "subjective" or "possible," defend their interpretations as if understanding text meaning were in principle the same activity as understanding sentence meaning. There is thus a case for developing humanities methodologies and practices which give the distinct nature of text meaning its due in a clearer manner.

\section{The Reading of Reading: The Case of Midrash}

One example of academics reading reading is the study of the rabbinic hermeneutics of the Bible, that is, Midrash. Constructivist approaches, such as deconstruction and intertextuality, have contributed significantly to the development of the field since the mid-1980s. In this section of my paper, I will review some of the new conceptions of Midrash that have emerged, and examine them in the light of the non-constructivist, phenomenological position given

57 The example of stretching out an arm is Nietzsche's; see Friedrich Nietzsche, Sämtliche Werke: Kritische Studienausgabe, vol. 12, Nachlass 1885-1887, ed. Giorgio Colli and Mazzino Montinari (Munich, Berlin: Deutscher Taschenbuch Verlag, De Gruyter, 1999), 249. In the inauthentic posthumous compilation known as Will to Power by Peter Gast and Elisabeth FörsterNietzsche, this is found as $\S 665$; see http://gutenberg.spiegel.de/buch/der-wille-zur-macht-i6029/26 (accessed 31/03/2015). Wittgenstein makes a similar point regarding arm movements; see Robert B. Pippin, Nietzsche, Psychology, and First Philosophy (Chicago: University of Chicago Press, 2010), 72. 
in the preceding section. One of the immediate gains of applying constructivist approaches to midrashic texts was a much more sophisticated understanding of the rabbinic approach to Scripture. This improved in particular on Yitshaq Heinemann's apologetic and misleading conceptualization of Midrash as "creative” philology or historiography. ${ }^{58}$ But Heinemann's influential view had already been an improvement on other attempts to account for midrashic hermeneutics. Quite common was, and still to some extent is, the use of reductive labels such as peshat and derash. The former, anachronistically defined as a contextually appropriate rabbinic reading of a given biblical passage, was easy to assimilate to modern Western philology, and its presence in midrashic texts was valued in contrast to derash, defined as fanciful. The role of the latter was played down, or conceded as being indefensible, even inexplicable. ("How does this interpretation work?" - “Oh, it’s just midrash.” - this is an answer I remember once receiving from a well-known academic during a class on midrashic texts.) The alleged derash dimension of Midrash was seen not as genuine interpretation, but as an epiphenomenon, a pretext for rabbinic normative or theological positions conceived away from the biblical text. Often that claim was justified by saying that, since the biblical wording had patently not prompted the rabbinic idea, the latter did not really constitute an interpretation. Post-modern approaches brought to the question of reading in general a salutary degree of sophistication, which helped to remove from the well-informed academic discussion of Midrash conceptually confused causal approaches to meaning, as well as naïve apologetics. Deconstruction and intertextuality brought a respectful expectation of complexity to studying how readers establish and respond to the meaning of texts. I have no doubt that this raised the bar for the whole field of Rabbinics, and that the current discourse on such matters demonstrates its beneficial effects. At first, under the inspiration of deconstruction in particular, the adoption of post-modern approaches sometimes took the form of a triumphalist view that, to put it bluntly, Midrash anticipated Derrida. ${ }^{59}$ The narrative went something like this: rabbinic Judaism refused to join Greeks and later Chris-

58 Itshaq Heinemann, Darkhey Ha-Aggadah (Jerusalem: Magnes Press, 1949); see Samely, Rabbinic Interpretation of Scripture, 1-17. Other scholarship had already begun to question such assumptions; see e.g. Arnold Goldberg's work on midrashic hermeneutics, now collected in his Mystik und Theologie des rabbinischen Judentums: Gesammelte Studien I, ed. Margarete Schlüter and Peter Schäfer (Tübingen: Mohr Siebeck, 1997) and Rabbinische Texte als Gegenstand der Auslegung: Gesammelte Studien II, ed. Margarete Schlüter and Peter Schäfer (Tübingen: Mohr Siebeck, 1999). 59 For a critical examination of such links, see David Stern, Midrash and Theory: Ancient Jewish Exegesis and Contemporary Literary Study (Evanstone, IL: Northwestern University Press, 1996), $15-17$ and passim. 
tians in their being dominated by "Western metaphysics," that is, binary logic, an idea of truth as limited to propositional truth, and the essentializing of meanings. By contrast, the rabbinic procedures of reading were seen as constructing the Bible as a text that embraces polysemy. Furthermore, these texts themselves transmitted disagreements on interpretation without resolving them, thus again avoiding an aspect of Graeco-Christian metaphysics. In particular the rabbis were taken to have resisted the assumption that (biblical) words, sentences and texts can have only one true meaning. ${ }^{60}$ Rabbinic Judaism avoided the Western original sin, so to speak, and midrashic texts could therefore be legitimately read as gloriously realizing Derrida's deconstruction and Bakhtin's dialogism avant la lettre. A second trend was to view Midrash in terms of a tendency to bring to prominence historical layers of Scripture which, at certain points in the composition/redaction of the Bible, were de-emphasized or covered up. Thus Midrash was depicted as working through the (biblically) repressed, for example, traces of ancient near Eastern myths. ${ }^{61}$ Finally, there was the notion that the midrashic approach reads the Hebrew Bible in an "intertextual" manner, on which more presently. Let us reflect for a moment on the contemporary setting of such interpretations of Midrash. First, they give Judaism a positive role in human history connected to present concerns. For the need to escape the clutches of logocentrism is, for the academics in question, an urgent and moral imperative of the present. Judaism is thus shown to be compatible with, if not anticipating, prestigious aspects of contemporary culture, similar to some earlier scholars seeing Midrash as a kind of philology, when it was philology that carried high academic prestige. Second, some Jewish Studies scholars agree with the post-modern view that Western logocentrism, rationality and technology paved the way

60 See among others, Handelman, The Slayers of Moses (note 9); José Faur, Golden Doves with Silver Dots: Semiotics and Textuality in Rabbinic Tradition (Bloomington, IN: Indiana University Press, 1986); Daniel Boyarin, Intertextuality and the Reading of Midrash (Bloomington, IN: Indiana University Press, 1990); James Kugel, "Two Introductions to Midrash," in Midrash and Literature, ed. Geoffrey H. Hartman and Sanford Budick (New Haven, London: Yale University Press, 1986), $77-103$, and other papers in the same volume; also Susan Handelman, "Fragments of the Rock: Contemporary Literary Theory and the Study of Rabbinic Texts - A Response to David Stern," Prooftexts 5 (1985): 73-95; Daniel Boyarin, "Shattering the Logos - or, The Talmuds and the Genealogy of Indeterminacy," in The Talmud Yerushalmi and Graeco-Roman Culture, vol. 3, ed. Peter Schäfer (Tübingen: Mohr Siebeck, 2002), 273-298. For an interpretation of the philosophical foundations of these developments, see the first section of Arkady Kovelman and Uri Gershowitz, "Hidden Allegory in the Talmud: The Ontology of Rabbinic Hermeneutics,” Review of Rabbinic Judaism 13 (2010): 141-193.

61 See Boyarin, Intertextuality, 93-104. 
for the efficient dehumanization on an industrial scale that is the Holocaust. ${ }^{62}$ This effectively implies that rabbinic Judaism, and thus much of traditional Judaism generally, remained untouched by instrumentalization of knowledge that stood in the service of murder, and the murder of Jews in particular.

In addition to discussions about the nature of Midrash more generally, the post-modern or constructivist study of it produced specific historical-literary claims. I will examine some constructivist positions on Midrash, starting with the claim that the rabbinic interpreters accepted biblical polysemy. This entails in particular that the Rabbis most responsible for the shaping of rabbinic hermeneutics are seen as having accepted the possibility of multiple and diverse meanings for the same biblical wording. The idea has been influential beyond Rabbinics and Jewish Studies, in particular in literary studies. ${ }^{63}$ There are some oftquoted general aphorisms and narratives scattered across rabbinic literature which appear to indicate that individual Rabbis endorsed a theory of the multi-valence of Scripture, ${ }^{64}$ and on their basis biblical polysemy is considered by some scholars to be "virtually an ideological cornerstone of rabbinic exegesis." ${ }^{65}$ Such general statements on a multi-valent Scripture are not, however, directly borne out by the myriad of specific interpretations of biblical passag-

62 Zygmunt Bauman, Modernity and the Holocaust (Cambridge: Polity, 1989); Robert Eaglestone, The Holocaust and the Postmodern (Oxford: Oxford University Press, 2004). But in their critique of Western rationality, post-modern philosophical critiques of Western metaphysics and technology are indebted to Heidegger, a name tainted for many by his own attitude to Jews. Some new material on this matter is discussed by Jean Grondin, "The Critique and Rethinking of 'Being and Time' in the First Black Notebooks," in Reading Heidegger's Blackbooks, ed. Ingo Farin and Jeff Malpas (Cambridge, MA: MIT Press, forthcoming), an early reaction to the publication of Martin Heidegger, Gesamtausgabe IV. Abteilung: Hinweise und Aufzeichnungen, Band 94: Überlegungen II-VI (Schwarze Hefte 1931-1938) (Frankfurt: Vittorio Klostermann, 2014).

63 For the latter see in particular Hartman and Budick, Midrash and Literature.

64 Some of the relevant passages are collected in Stern, Midrash and Theory, 17-23; Azzan Yadin, Scripture as Logos: Rabbi Ishmael and the Origins of Midrash (Philadelphia, PA: University of Pennsylvania Press, 2004), in particular regarding Mekhilta de-Rabbi Ishmael Bahodesh 7, on Exod 20:8, Babylonian Talmud Sanhedrin 34a (not 34b as erroneously stated in Yadin, p. 78) and Shabbat 88b; Boyarin, "Shattering the Logos"; Marc Hirshman, "Aggadic Midrash," in The Literature of the Sages: Second Part, ed. Shmuel Safrai, Zeev Safrai, Joshua Schwartz, and Peter J. Tomson (Assen, Minneapolis, MN: Van Gorcum and Fortress, 2006), 107-132, here at 118-119.

65 Thus Stern, Midrash and Theory, 18. Stern's account is somewhat representative in another respect, namely in not separating clearly the evidence of a rabbinic acceptance of biblical polysemy from the evidence for a rabbinic acceptance of the legitimacy of rabbinic disagreements, including disagreements on biblical interpretation; see op. cit. 21. These are not the same thing, and evidence for the latter is overwhelmingly strong, while evidence for the former is much more indirect. 
es one actually finds in midrashic texts, except that divergent interpretations of the same biblical passage are often tacitly juxtaposed. ${ }^{66}$ The juxtapositions are tacit in the sense that there is no explanation of their meaning, and no evaluation of the apparently competing claims; there is thus no acknowledgement that the adjacent interpretations are competing with each other. Rabbinic interpretations of the same biblical passage, let us call it X, can clash in two different ways. (1) Contradictory propositions or norms are ascribed to the same biblical $\mathrm{X}$ : A and non-A; or, (2) The same biblical word, phrase, sentence or group of sentences $\mathrm{X}$, is seen as speaking about two entirely disparate topics, $\mathrm{N}$ and $\mathrm{M}{ }^{67}$ the two norms or propositions are not contradictory, but merely divergent meanings of $\mathrm{X}^{68}$ Now, midrashic works tend to present rival interpretations of the first kind, which are incompatible by logic, as disputes between different voices, while using either the dispute format or tacit juxtaposition for the second scenario, that is, disparate topics N/M ascribed to the same biblical passage. As far as the level of the midrashic text is concerned then, only polysemy of the second type (N/M) can be suspected of being implied in tacit juxtapositions. The quoted Rabbis themselves are often depicted as lustily arguing against each other's interpretations, which suggests that they did not accept biblical polysemy in general. And single Rabbis are, in my recollection, extremely rarely reported as proposing mutually competing interpretations on a single occasion, that is, as claiming at the same time two disparate topics $\mathrm{N}$ and $\mathrm{M}$ for the same biblical $\mathrm{X}$; let alone two mutually contradictory meanings $\mathrm{A}$ and non-A. ${ }^{69}$ But from the fact that Rabbis are not routinely presented as endorsing specific biblical polysemy does not follow that the attitude of midrashic text makers was the same. ${ }^{70}$ We must at least initially separate evidence for the views which midrash-

66 As Daniel Boyarin says, "This ... again supports both the argument of Yadin as well as the larger argument that the notion of Scriptural polysemy belongs to a relatively late layer in the formation of rabbinic textuality, one that can be found in the redaction of the midrashic texts and narrative and in theoretical formulations virtually exclusively in the Babylonian Talmud" ("Shattering the Logos," 298).

67 The Database, ed. Samely et al., contains a category for commentary works related to this: 6.7. The features of disputes (6.7.3.3/4) and attributions to Rabbis (6.8) are also documented. 68 For the rabbinic recontextualization of pieces of Scriptural wording, a crucial aspect of rabbinic hermeneutics more generally, see Samely, Rabbinic Interpretation of Scripture in the Mishnah, 59-80 ("The Imposition of a Perspective on Scripture").

69 But see the claim of Hirshman, "Aggadic Midrash," that "we do have on record, in a number of places in the midrash, the attempt of a single sage to offer multiple aggadic interpretations of a single verse." He refers to Bereshit Rabbah 52.11 and 70.8 (R. Hanin, on Gen 20:13 and 29:2-3). 70 See Stern, Midrash and Theory, 33-34; cp. Samely, Forms of Rabbinic Literature and Thought, 97-115 (“The Literary Device of Quoting Rabbis”); 71-73 (on biblical interpretation 
ic texts ascribe to the characters they present, "Rabbis," from evidence of the views of the makers of these texts. The latter evidence arises largely from the manner in which they shaped their texts, for their own voices do not appear on the text surface. In the case we are here concerned with, the evidence consists in the literary arrangement of tacit juxtaposition. Mere juxtaposition is actually a very common structuring principle in rabbinic literature, across different genres of texts. Smaller units of information, apparently self-contained and formally bounded, are often placed next to each other without any explanatory further text. $^{71}$ With regard to the case of juxtaposed interpretations in midrashic works, it is perfectly possible, indeed likely, that the use of juxtaposition of interpretations that ascribe disparate topics to the same piece of Scripture indicates an acceptance of certain types of biblical polysemy. That would seem to indicate that the hermeneutics of the midrashic text makers differed in a very important respect from the hermeneutics they ascribe to the Rabbis they quote. ${ }^{72}$ However, the format is ambiguous. ${ }^{73}$ It may be seen merely as a way to display and record the voices of tradition. Or it may mean different things in different periods, contexts and midrashic works, and require to be linked to other literary or thematic features before one can discover the implied message. So, one can argue from the format of mere juxtaposition that the makers of at least some midrashic texts accepted certain kinds of biblical polysemy in actual interpretations, although that is not certain. But the midrashic evidence itself does not allow us to ascribe such acceptance, in the actual practice of interpretation, to Rabbis of all periods or in general.

Turning to the claim that rabbinic readings of Scripture are "intertextual," rabbinic hermeneutic practice does indeed treat Scripture as a "self-glossing text," as Daniel Boyarin says. ${ }^{74}$ This interpretation of rabbinic practice brings out a key characteristic of hermeneutic procedures as used, for instance, in the Petihah. ${ }^{75}$ The Petihah is a literary format that looks at one, usually narrative,

specifically); and recently with regard to the Babylonian Talmud in particular, Moulie Vidas, Tradition and the Formation of the Talmud (Princeton, NJ: Princeton University Press, 2014). 71 See Samely et al., Profiling, 199-205 and 222-223. Many illustrations of this will be found in the online Database, ed. Samely et al., using points 5.7 and 6.1 .4 as search terms.

72 See further Stern, Midrash and Theory, 33-34; Boyarin, "Shattering the Logos," 277-280.

73 As emphasized by Boyarin, "Shattering the Logos," 280-283.

74 Boyarin, Intertextuality, 39.

75 Boyarin, Intertextuality, 110-116; Arnold Goldberg, "Versuch über die Präsupposition und Struktur der Petihah," in Rabbinische Texte als Gegenstand der Auslegung: Gesammelte Studien II, 303-346; Samely, Forms of Rabbinic Literature, 74-76; 178-199; Kugel, "Two Introductions"; Samely, Rabbinic Interpretation of Scripture, 110-147; Samely, "Literary Structures and Historical Reconstruction: The Example of an Amoraic Midrash,” in Rabbinic Texts and 
biblical passage in the light of a second, unrelated one, usually a generic or figurative statement. It thereby reads Scripture across its different books and there are other midrashic procedures which also do this. This is taken to suggest that Midrash approached Scripture in the way in which post-modern scholars of intertextuality approach all texts, namely by tracing out how texts are always read through the prism of other texts, and by not assigning priority or ultimate meanings. This post-modern or constructivist intertextuality is not restricted to cases where there are historical commonalities or links between texts. But midrashic linkages between biblical books, which remain within the canon of the rabbinic Bible, can often be seen as following the same inner-canonical echoes or clues within Scripture that the scholars of European historical-critical analysis also identified, as being due to processes of adaptation, redaction, allusion, quotation, shared oral dependency or Fortschreibung. In other words, Midrash pins down to some extent what modern biblical studies identify as historical commonalities, links and dependencies between parts and layers of the Hebrew Bible. As the field of biblical studies shows, such pinning down is perfectly compatible with the idea of recovering an original text meaning. Intertextuality in the constructivist sense sees this differently; it tasks itself with showing how meaning is always disseminated along lines that exceed historical influence and authorial intention, by routes that are at least partly non-deliberate. Midrash, however, only identifies as "inter-texts" passages within the rabbinic canon of the Hebrew Bible. It strenuously avoids following up the traces which other texts and cultural meanings that formed part of the horizon of the Rabbis, from Hellenistic philosophy to extra-canonical Jewish and Christian writings and traditions, will have left in rabbinic interpretations (in the modern historian's assessment, at least). If their approach to Scripture had truly been comparable to today's constructivist intertextuality, the canon boundaries would not have limited their interest. They would have brought into play extra-canonical and non-Jewish texts and traditions in the same way in which they use canonical quotations. ${ }^{76}$ Their practice is thus not intertextual. Indeed it arises from assumptions opposed to those of intertextuality, including a divine

the History of Late-Roman Palestine, ed. Martin Goodman and Philip Alexander (London: Oxford University Press, the British Academy, 2010), 185-216.

76 Ben Sira (Sirach in the Septuagint) is the only extra-canonical work that rabbinic texts occasionally quote. See T. Ann Ellis, "Negotiating the Boundaries of Tradition: The Rehabilitation of the Book of Ben Sira (Sirach) in B. Sanhedrin 100b," in Sacra Scriptura: How "Non-Canonical” Texts Functioned in Early Judaism and Early Christianity, ed. James H. Charlesworth and Lee M. McDonald, with Blake A. Jurgens (London: Bloomsbury, 2014), 46-63; Jenny R. Labendz, "The Book of Ben Sira in Rabbinic Literature," AJS Review 30 (2006): 347-392. 
author. This author may have provided an inexhaustible potential of signification in the view of some Rabbis, but used his power to mean all those meanings one may discover in the one text that he sanctioned, the canonical Bible. ${ }^{77}$

\section{The Scholar as Reader of Reading}

The focus of my reflections in this paper has been Jewish Studies insofar as they are concerned with texts that read earlier texts. Since much historical scholarship involves reading written sources, theories of reading influence the study of certain parts of Jewish culture in a double way: regarding the methodology by which the scholar reads any text from the Jewish past, whatever of its content may be; and regarding the methodology by which the scholar reads a younger text's reading of an older text, that is, a source whose content is the interpretation of a text also known to us. In the second scenario the scholar is drawn into an anachronistic experience. For the scholar who has access to both the interpreting text and the interpreted one, and tries to understand the former as a reading of the latter, must try to perform that particular reading herself or himself, but also reads the older text independently, as a modern scholarly interpreter. If the scholar does not succeed in understanding the younger text's interpretation, he or she thereby judges it, becomes involved, takes sides. But that is unavoidable. When reading Thucydides on the war of Spartans and Athenians, we are not forced to side with one or the other. By contrast, we are obliged to take sides when evaluating hermeneutic procedures in historical sources. We have to check them against our own reading of the texts they interpret, because we cannot otherwise access those procedures, which constitute precious evidence for what a culture was like. But for the same reason we cannot read their reading of the original text in a neutral mode. We have to see the original text with our own eyes also, in order to understand what it means to read it through their eyes. So we either suspend our disbelief in the younger source's interpretation in order to appreciate it, or we recognize it as coinciding with our own reading; or, very rarely, we change our own reading to agree with its reading. But whatever we do there is no middle ground here, no proper historical distance: the hermeneutic practice captured in a historical source stands in prima facie competition with whatever reading methods the modern scholar her-

77 One of the expressions of this unity of signification is found in Babylonian Talmud Hagigah 3b, discussed in Stern, Midrash and Theory, 19. 
self or himself is using. ${ }^{78}$ Hence the strong scholarly urge to defend Midrash, be it as philology or as deconstruction. The alternative is rightly suspected to be akin to a condemnation of midrashic readings. Such a condemnation, just as any endorsement, goes against the grain of the historical outlook. Yet we do not have the option just to step back and let the ancient culture do its thing; merely to describe the interpretation in detached terms. Reading non-scholarly reading methods tangles with our scholarly reading, and affects the way we read the younger source. This hermeneutic circularity in the scholarly reading of reading is not the result of adopting constructivist views; it emerges from within the conventional assumptions of historiography. The reading of reading, just as much as the disparity between the experiences of text and sentence meaning, treated above, puts into question some assumed certainties in the practice of the non-constructivist scholarly reading of sources.

78 Cf. Samely, Rabbinic Interpretation of Scripture, 6-10; Forms of Rabbinic Literature, 70-73. 
Bereitgestellt von | De Gruyter / TCS Angemeldet

Heruntergeladen am | 14.07.16 10:40 